\title{
CONSUMERS DEMAND ON HALAL COSMETICS AND PERSONAL CARE PRODUCTS IN INDONESIAN
}

\author{
Muniaty Aisyah
}

\begin{abstract}
Consumers Demand on Halal Cosmetics and Personal Care Products in Indonesian. This research aims to analyze the influential factors involved in Moslem consumers' decision to purchase halal cosmetics and personal care products in Indonesia by using the Theory of Planned Behavior. 100 questionnaires were analyzed using Structural Equation Modeling, collected from respondents of female consumers who purchased Wardah cosmetics and personal care products in South Jakarta and South Tangerang. The findings show that attitude, subjective norm, perceived behavioral control and purchase intention are positively related to the consumers' decision to purchase halal cosmetics and personal care products. By addressing the consumers' traits that can predict halal cosmetics and personal care products necessity, marketers could generate proper marketing strategies to validate consumers' demand which in turn will stimulate the growth of halal products industry in Indonesia.
\end{abstract}

Keywords: halal, cosmetics, personal care products, consumers purchase behavior, theory of planned behavior

Abstrak. Permintaan Konsumen pada Kosmetik Halal dan Produk
Perawatan Pribadi di Indonesia. Penelitian ini bermaksud menganalisis
faktor-faktor yang mempengaruhi keputusan konsumen Moslem membeli
kosmetik dan produkperawatan tubuh berlabel halaldi Indonesia. 100 kuesioner
dianalisis menggunakan Structural Equation Model yang dikumpulkan dari
para responden khususnya konsumen wanita yang telah membeli kosmetik
dan produk perawatan tubuh halal bermerek Wardah di Jakarta Selatan dan
Tangerang Selatan. Hasil penelitian ini menunjukkan bahwa sikap, norma
subyektif, kontrol perilaku yang dirasakan, dan niat beli konsumen berpengaruh
positif terhadap keputusan konsumen membeli kosmetik dan produk perawatan
tubuh berlabel halal. Dengan mempelajari perilaku pembelian konsumen yang
dapat memprediksi kebutuhan akan kosmetik dan produk perawatan tubuh
berlabel halal, pemasar dapat merancang strategi pemasaran yang tepat, guna
memenuhi kebutuhan konsumen yang pada gilirannya akan dapat merangsang
pertumbuhan industri produk halal di Indonesia.

Kata kunci: halal, kosmetik, produk perawatan tubuh, perilaku pembelian konsumen, teori planned behavior 


\section{Introduction}

Since the dawn of civilization, food and pharmaceutical products (drugs, cosmetics and personal care products) have been some of the earliest human needs (Mursidi, 2013). However, Moslems have strict religious guidelines with regard to consumption and use. Allah commands Moslems to consume only things that are Halal (i.e. religiously permissible) and good (Al Qur'an, 23:51). Thus, it is an obligation for Moslem to consume and use only halal products (Rezai et.al, 2009; Salehudin and Luthfi, 2011; Rahim and Junos, 2012).

In the Arabic language, Halal refers to anything that is permissible under Islamic law (Sharia). It is usually used to describe activities that a Moslem is permitted to engage in, i.e. eat, drink or use. The antithesis of halal is Haram, which in the Arabic language refers to anything prohibited under Islamic law. Accordingly, halal products are those that are Sharia compliant, i.e. do not involve the use of Haram (prohibited) ingredients, exploitation of labor or environment, and are not harmful or intended to harm (Omar et.al, 2012). The Prophet Muhammad, also forbids Moslem to avoid consuming things are ambiguous whether it is halal or haram (Imam Nawawi, Hadist by Bukhari and Muslim). These commandments regulate the lives of Moslems worldwide and its compliance are mandatory (Soesilowati, 2010; Salehudin and Luthfi, 2011).

The realm of halal may extend to all consumables such as pharmaceuticals, cosmetics, personal care products, toiletries, etc. The halal label or certificate not only guarantees Moslems what they consume or use is in accordance to Islamic law, but also encourages manufacturers to meet the halal standard. In the scope of halal cosmetics and personal care products, the concept covers critical aspects of production such as halal ingredients and usage of permissible substances which must be manufactured, stored, packaged and delivered in conformity with Sharia requirements (Elasrag, 2016). Thus, halal labeling and certification can play an important role to assure Moslem consumers that the products they purchase meet the necessary religious requirements and conditions (Omar et.al, 2012). Currently, there are numerous food, pharmaceuticals, cosmetics and personal care products available with nonspecific labeling. Therefore, the halal verification and authentication of these products is urgently required (Mursyidi, 2013).

From a Moslem perspective, knowing the origin of raw materials and production process of consumer items is essential due to the Sharia obligation stating that any Moslem must consume only halal and wholesome products. This situation is increasingly important since the verification and authentication of halal products is paramount in order to maintain the sanctity of the Islamic religion (Mursyidi, 2013). In order to protect the rights of Moslem consumers and their efforts to 
follow their commandments in consuming only halal products, halal certification institutions have emerged in several countries to provide certification for food, beverages, pharmaceuticals, cosmetics and personal care products that are halal or not containing haram (prohibited) components (Salehudin and Luthfi, 2011).

Malaysia has taken a serious approach towards developing halal products since 2009 because it realized that halal considerations is the new attraction for the country's Moslem customers. For cosmetics firms that operate in competitive markets, achieving satisfaction for their customers is particularly important if they want to survive in those markets. Satisfied customers will repeat their purchases and they will be more loyal to the firm (Yoe et.al, 2016). The Malaysia External Trade Development Corporation Halal Unit informed that halal cosmetics and personal care products as well as halal food and beverages were the only segments that reported an increase in exports during in the first half of 2015 while other halal ingredients, palm oil derivatives and industrial chemicals recorded a decrease (Rasid, 2016).

According to a Thomson Reuters report, global Moslem spending on cosmetics increased one per cent to US $\$ 46$ billion globally in 2013 . This spending was 6.78 percent of the global sector expenditure and is expected to reach US\$73 billion by 2019. Based on 2013 estimates, top countries with Moslem cosmetics consumers are the United Arab Emirates (US\$4.9 billion), Turkey (US\$4.4 billion), India (US\$3.5 billion), and Russia (US\$3.4 billion) (Rasid, 2016). Another study in 2015, conducted by the Institute of Personal Care Science of Australia, calculated that the global cosmetic industry was worth approximately US\$334 billion, with halal cosmetics contributing to US\$13 billion of this amount a year (Ramli, 2015). According to Malaysian Halal Industry Development Corp (HDC), Moslems have begun to look for halal cosmetics and personal care products. Moslem consumers, with global population of nearly two billion, are increasingly aware that some cosmetics contain ingredients derived from animal origins and are thus concerned about the halal status (Rasid, 2016). The increasing awareness among Moslem consumers regarding halal cosmetics and personal care products has attracted the attention of the cosmetics retailers (Abd Jabar et.al, 2012).

Indonesia, country with the largest number of Moslems in the world, is a large potential market for consumables such halal cosmetics and personal care products. The increasing preference for halal cosmetics and personal care products in Indonesia is evident from MarkPlus Insight Women Survey in 2015 which shows that Wardah — which positions itself as a Moslem-friendly, halal cosmetics brandwas named the most popular cosmetics brand for women. The survey conducted in mid-2015 included 1,183 female respondents across 18 cities in Indonesia, aged between 15 and 59 years. According to the result, $37.8 \%$ of the respondents claimed 
Wardah to be their favorite cosmetics brand, followed by Pixy (10.1) and Sari Ayu (8.7\%). Ponds and VIVA were at fourth and fifth spot, with negligible margin. Apart from Wardah, Sari Ayu too is certified halal (MarkPlus, 2016).

The increasing preference of local halal brand cosmetics like Wardah, Sari Ayu and many other products from overseas with halal certification indicates consumers demand on halal cosmetics and personal care products in Indonesia is increasing. Consumer demand is the willingness and ability of consumers to purchase a quantity of products in a given period of time, or at a given point in time (Economicsonline, 2016). As the largest Moslem population in the world, it is no surprise that halal cosmetics have caught on in Indonesia. To set up business plan to penetrate the potential market, local and foreign marketers must have proper understanding of the consumers and operate carefully in order to avoid offending Moslem consumers and obtain good and halal foothold in the market like Indonesia. For a product to be halal, it should not contain alcohol, should not be tested on animals, and should not contain ingredients from animals. The desire to comply with the commandment in consuming only halal products could create consumers' involvement and influence in purchasing or choosing what product they consume (Salehudin and Luthfi, 2011). By discovering the influential factors involved in consumers' decision to purchase halal cosmetics and personal care products enables marketers to extend their production in Indonesia as well as in global halal market. In order to understand how cosmetics and personal care products with halal labeling or certification influence the purchase decision of Moslem consumers, a theoretical framework is necessary.

Lada et.al. (2009) discovered that the Theory of Reasoned Action (TRA) is applicable to describe Moslem consumers' intention to choose product with halal label. TRA suggests that the best predictor of behavior is intention. Intention is a function of a person's attitude and subjective norm toward the behavior. Intention is the cognitive representation of a person's readiness to perform a given behavior, and it is considered to be the immediate antecedent of behavior. TRA was further developed into the Theory of Planned Behavior (TPB) by Ajzen (1985, 1991, 2006) by adding a third belief, perceived behavioral control, to increase its domain of explanation which is the self-efficacy of the individual regarding certain behavior (Salehudin and Luthfi, 2011).

This research aims to test the applicability of Theory of Planned Behavior in explaining how halal labeling influence Moslem consumers to purchase cosmetics and personal care products especially in Indonesia, as a potential market for halal products. By analyzing consumers purchase behavior using the Theory of Planned Behavior, this research could predict the consumers demand on halal cosmetics and personal care products and its influential factors in Indonesian market. There are 
two behavior of the Moslem consumers in which the model will be tested, first is the purchase intention, and the second is the purchase decision on halal cosmetics and personal care products.

In particular, this research has three specific objectives. First, to test whether the Theory of Planned Behavior is applicable to explain the influential factors involved in consumers' decision to purchase halal cosmetics and personal care products. Second, to identify whether consumers' attitude, subjective norm, perceived behavioral control and purchase intention influence consumers' purchase decision. Third, to identify whether purchase intention is an intervening variable, which indirectly influences or mediates consumers' attitude, subjective norm, and perceived behavioral control toward their purchase decision on cosmetics and personal care products with halal label. This research is structured as follows: first, introduction; second, the literature review; third, research method; fourth, result and discussion; and the last is conclusion.

\section{Literature Review}

According to the Theory of Planned Behavior (TPB) model by Ajzen (1985, 1991), an individual's performance of certain behavior is determined by his or her intention to perform that behavior. Intention defines as an immediate antecedents of behavior (Ajzen and Fishbein, 1975). Thus, it assumes that the probability of performing an act is a function of intention to perform the act (Chang and Cheung, 2001). There are three components in Theory of Planned Behavior that explain further intention to behave and thus behavior itself (Ajzen, 2006), such as: attitude, subjective norm and perceived behavioral control (see Figure 1).

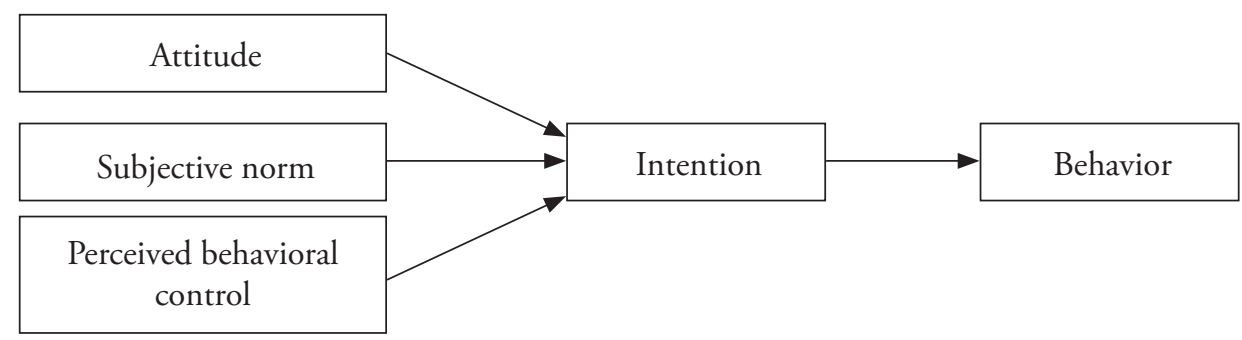

Figure 1. Theory of Planned Behavior (TPB) Model (Ajzen, 1985, 1991)

Attitude is the psychological tendency that is expressed by evaluating a particular entity with some degree of favor or disfavor (Eagly and Chaiken, 1995). Attitude towards the behavior refers to the degree to which a person has a favorable or unfavorable evaluation or appraisal of the behavior in question. The TPB model determined that the more favorable the attitude with respect to a behavior, the 
stronger is the individual's intention to perform the behavior under consideration. The stronger the attitude, the stronger the intention will be, thus this will show in the purchase decision behavior and vice versa (Ajzen, 2008). In many societies, religion plays an influential role shaping product purchase behaviors. Considerable evidence indicates that religion can influence consumer attitude and behavior in general, and product purchasing or consuming habits in particular (Rahim and Junos, 2012). According to Salehudin and Luthfi (2011), attitude indicates individual belief about the personal evaluation regarding the good compliance to the commandment about halal consumption. The stronger the attitude, the stronger the consumer's intention and decision to purchase halal products.

Subjective norm refers to the perceived social pressure to perform or not to perform the behavior (Ajzen, 1991). The TPB model holds subjective norm as a function of belief. It is the function of how consumer's referent others (i.e. parents, family, and friends) and view the regarding behavior and how motivated the consumer is to comply with those beliefs (Miller, 2005). Beliefs play important roles in performing the intention of consumers (Ajzen and Fishbein, 1985). In the context of Islam, a religious society adheres to the teachings of their Prophet Muhammad who embraced and displayed exemplary behavior to his followers. As a result, the influence of Prophet Muhammad will have a positive effect on subjective norm thus affecting the intention to behave accordingly (Rahim and Junos, 2012). Subjective norm deals with consumers' motivation and behavior, which is constructed to incorporate the expectations of the approval or disapproval of others important to him or her (Chen, 2008). According to Rahim and Junos (2012), if consumers believe those people important to them think that products with halal label is essential, they will have a higher intention of purchasing such products. The influence of significant others will have a positive effect on subjective norm thus affecting the intention and behavior accordingly.

Based on the TPB model, perceived behavioral control describes perceptions of the extent to which the behavior is considered to be controlled. It can account for considerable variance in behavioral intention and decision (Ajzen, 1991). The link between perceived behavioral control and behavior suggests that consumers are more likely to engage in behavior they feel they have control over and prevented from carrying out behavior over which they feel they have no control (Rezai et.al, 2009; Rahim and Junos, 2012).

Moslem's intention to accept halal products is also determined by the control they feel they have over such behavior. Perceived behavioral control positively influence consumers' intention toward accepting products by the religious society. For the religious society, accepting halal products is something that should be within their control. Consumers who consider themselves to be more or less Moslems, are 
sometimes also primarily guided by the important factors attached to halal products such as whether it is easy or difficult to purchase or get the product and the ease or difficulty to consume the product (Rahim and Junos, 2012). Providing that when consumers believe they have more resources and opportunities needed such as time, money, skills, and control to perform religious obligation and the availability of the products (Ajzen, 1991; Miller, 2005; Rezai et.al, 2009; Rahim and Junos, 2012; Omar et.al, 2012). High perceived availability of halal products in a country may hinder consumers in that country from consuming other products (Rezai et.al, 2009). Intention and decision to purchase halal products is higher when consumers perceive more control over purchasing these products (Omar et.al, 2012).

Therefore, it can be concluded that a positive personal attitude towards the consumption of halal cosmetics and personal care products, the positive influence of other important people, the positive perceived behavioral control over consuming halal cosmetics and personal care products, will predict the consumers' intention and their decision to purchase halal cosmetics and personal care products.

\section{Methods}

The method of analysis employed to the hypotheses in this research is Structural Equation Modeling (SEM). SEM is an analysis method employed to test structural models that depicts structural relationships between latent constructs. When this research is translated into the hypotheses model (see Figure 2), observed variables are drawn with the error terms for each latent variable. For the exogenous variables, attitude $(\mathrm{x} 1)$ contains ten observed variables, while subjective norm $(\mathrm{x} 2)$ and perceived behavioral control $(\mathrm{x} 3)$ each one contains eight observed variables. For endogenous latent variables, halal cosmetics and personal care products purchase intention (y1) and purchase decision (y2), the observed variables of each, contains two variables. For structural equation model, the error of each item is drawn as unobserved variables in round circles.

This research used convenience sampling method. Respondents were female Moslem consumers who live in South Jakarta and South Tangerang who already purchased and used Wardah brand as the halal cosmetics and personal care products. Wardah is one of the most popular halal cosmetics and personal care pro ducts brand in Indonesia. For cosmetics are included compact powder, two way cake powder, face powder, lipsticks, lip gloss, foundation, eyeliner, eye shadow, and make up remover. For personal care products are included lip balm, hand and body lotion, body butter, eau de toilette, body mist, roll on, facial wash, facial scrub, face toner, sun screen gel, oil massage, cream moisturizer and acne gel. Each respondents use minimum two items of these products for daily need. 
This research used questionnaires as instrument to obtain the primary data needed. The questionnaire consists of 5 point of Likert scale to evaluate the level of agreement of the respondents. There were 154 questionnaires distributed during the data collection period to target the respondents. The data was analyzed using Structural Equation Model (SEM), AMOS 22 version. From 154 observation number, there were 54 data profile causing outliers. After removing the outliers, there were 100 data used for this research. The next step was to see the level of normality data used. The result shows that the value of critical ratio $(\mathrm{CR})$ of data multivariate is 2.484 , which is in the range of -2.58 and 2.58 , hence the data is normal.

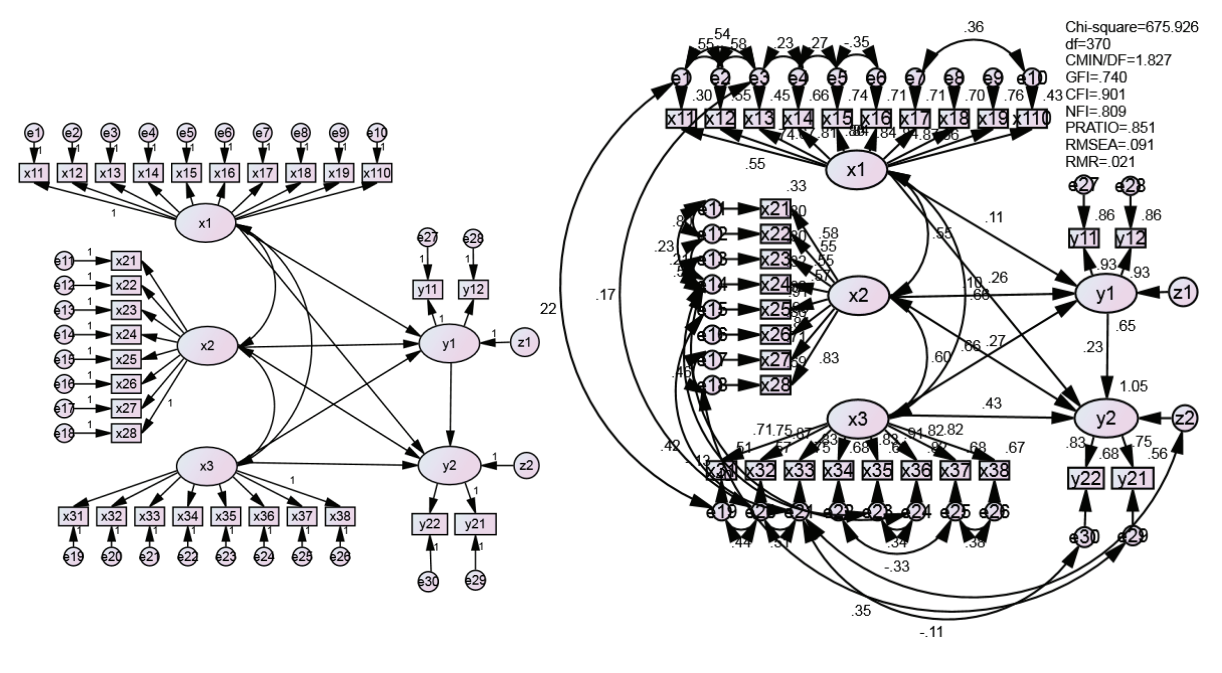

Figure 2. Hypotheses Model

Figure 3. Modification Model

\section{Result and Discussion}

\section{Result}

Respondents are female Moslem consumers who live in South Jakarta and South Tangerang area who already purchased Wardah brand as halal cosmetics and personal care products which are one of the most popular halal cosmetics and personal care products brand in Indonesia. Their age range averages is between 20 to 35 years old (55\%), above 35 years old is $40 \%$, and only $5 \%$ under the age of 20. Respondents' expenditure per month mostly average Rp.1,000,001 to Rp.2,500,000 (61\%), followed by Rp.2,500,001 to Rp.5,000,000 (16\%), 9\% above Rp.5,000,000, and 14\% are under Rp.1,000,000.

This research also characterized the religious orientation of the respondents which consists of: (1) ignorant: I do not know how to pray; (2) less obedient: Sometimes I forget to pray; (3) moderate: I carry out my religious obligation as long 
as able to do so; (4) obedient: I always try to perform my religious obligations; (5) very obedient: I always perform my religious obligations. The distribution shows that $40 \%$ of the respondents are obedient, 36\% are moderate, and $22 \%$ are less obedient, and $2 \%$ very obedient.

In the scope of halal cosmetics and personal care products, the critical aspects comes from the production especially the sourcing of halal ingredients and the usage of permissible substances such as gelatin, placenta, collagen, etc. Halal cosmetics and personal care products must also be manufactured, stored, packaged, and delivered in conformity with Islamic religious requirements. According to the survey, $42 \%$ of the respondents do not understand the existence of potential non-halal ingredients and the usage of permissible substances in cosmetics and personal care products. Moreover, the survey also shows that $30 \%$ of the respondents often inspect the halal label on cosmetics and personal care products packaging before buying, while $41 \%$ rarely inspect the halal label, and $29 \%$ of them never inspect the halal label before buying.

Confirmatory factor analysis (CFA) was conducted on every measurement model. The goodness of fit is the decision to see the model fit into the variancecovariance matrix of the dataset. The CFA of measurement model has a good fit with the data based on assessment criteria such as Statistic Chi-Square (X2), CMIN/ df, p-value Goodness Fit Index (GFI), Normed Fit Index (NFI), Comparative Fit Index (CFI), PRATIO, Root Mean Square Error Approximation (RMSEA), and Root Mean Square Residual (RMR).

Table 1. Goodness of Fit Model

\begin{tabular}{lccccc}
\hline $\begin{array}{c}\text { Goodness of Fit } \\
\text { Index }\end{array}$ & $\begin{array}{c}\text { Cut-off } \\
\text { Value* }\end{array}$ & Indicator & Status & $\begin{array}{c}\text { Revised } \\
\text { Indicator }\end{array}$ & $\begin{array}{c}\text { Status } \\
\text { (after Modification) }\end{array}$ \\
\hline Chi-Square $\left(\mathrm{X}^{2}\right)$ & Closed to 0 & 1048.852 & Poor Fit & 675.926 & Poor Fit \\
CMIN/ df & $<2$ & 2.669 & Poor Fit & 1.827 & Goodness of Fit \\
p-value & $>0,05$ & 0.000 & Poor Fit & 0.000 & Poor Fit \\
GFI & $>0.90$ & 0.623 & Poor Fit & 0.740 & Poor Fit \\
CFI & $>0.90$ & 0,788 & Poor Fit & 0.901 & Goodness of Fit \\
NFI & $>0.90$ & 0,703 & Poor Fit & 0.809 & Marginal Fit \\
PRATIO & $>0.90$ & 0,903 & Goodness of Fit & 0.851 & Marginal Fit \\
RMSEA & $<0,10$ & 0,142 & Poor Fit & 0.091 & Goodness of Fit \\
RMR & $<0,10$ & 0.130 & Poor Fit & 0.021 & Goodness of Fit \\
\hline
\end{tabular}

*Source: Hair et.al (2006), Haryono and Parwoto (2012) 
After several modification indices verifications (see Figure 3), the confirmatory factor analysis of measurement model in this research indicates four adequate goodness of fit model and two marginal fit (see Table 1). Thus, it means that the Theory of Planned Behavior model is fit and applicable to explain the influential factors involved in consumers' decision to purchase halal cosmetics and personal care products.

Table 2. Construct Validity Measurement

\begin{tabular}{|c|c|c|c|c|c|c|c|c|}
\hline Variable & Indicator & SLF & Variable & Indicator & SLF & Variable & Indicator & SLF \\
\hline \multirow{10}{*}{$\begin{array}{l}\text { Attitude } \\
\text { (x1) }\end{array}$} & $\mathrm{x} 11$ & .549 & \multirow{8}{*}{$\begin{array}{l}\text { Subjective } \\
\text { norm (x2) }\end{array}$} & $\mathrm{x} 21$ & .575 & \multirow{6}{*}{ control (x3) } & x33 & .866 \\
\hline & $\mathrm{x} 12$ & .739 & & $\mathrm{x} 22$ & .547 & & x34 & .827 \\
\hline & $\mathrm{x} 13$ & .672 & & $x 23$ & .549 & & x35 & .825 \\
\hline & $\mathrm{x} 14$ & .813 & & $\mathrm{x} 24$ & .567 & & x36 & .906 \\
\hline & $\mathrm{x} 15$ & .859 & & $\mathrm{x} 25$ & .908 & & x37 & .823 \\
\hline & $\mathrm{x} 16$ & .843 & & $\mathrm{x} 26$ & .926 & & x38 & .816 \\
\hline & $\mathrm{x} 17$ & .843 & & $\mathrm{x} 27$ & .842 & \multirow{2}{*}{$\begin{array}{c}\text { Purchase } \\
\text { intention }(y 1)\end{array}$} & y11 & .929 \\
\hline & $\mathrm{x} 18$ & .838 & & $x 28$ & .831 & & y12 & .927 \\
\hline & x19 & .870 & \multirow{2}{*}{$\begin{array}{l}\text { Perceived } \\
\text { behavioral }\end{array}$} & $\mathrm{x} 31$ & .714 & \multirow{2}{*}{$\begin{array}{c}\text { Purchase } \\
\text { decision (y2) }\end{array}$} & y21 & .750 \\
\hline & x110 & .659 & & x32 & .754 & & y22 & .826 \\
\hline
\end{tabular}

SLF: Standardized Loading Factor

Before the hypotheses can be tested, another step of analysis required is testing the construct validity of the measurement used in this research. Good construct validity of the instrument must be established before any conclusion about the causal relationship among constructs can be determined. The result showed a construct validity measurement model with all standardized loading factors greater than 0.5 (see Table 2). It means that construct validity of all items are established.

Before discussing the hypotheses result, this research also used descriptive statistics test to describe the consumers' behavior level by using mean value as the type of estimate of central tendency (Ghozali, 2011; Morgan et.al., 1999). Table 3 below shows that consumers have high level of attitude, subjective norm, perceived behavioral control, intention and decision to purchase halal cosmetics and personal care products with mean value from 4.22 to 4.32 . 
Table 3. Descriptive Statistics

\begin{tabular}{lccccc}
\hline & N & Min. & Max. & Mean* & Std. Dev. \\
\hline Attitude & 100 & 3.80 & 5.00 & 4.3190 & .39764 \\
Sub. Norm. & 100 & 3.47 & 5.00 & 4.2247 & .36222 \\
PBC & 100 & 3.62 & 5.00 & 4.2262 & .35864 \\
Intention & 100 & 3.65 & 5.00 & 4.2255 & .35460 \\
Decision & 100 & 3.64 & 5.00 & 4.2219 & .35707 \\
Valid N (listw.) & 100 & & & & \\
\hline
\end{tabular}

*Level: $1-2=$ very low, $2.1-3=$ low, $3.1-3.5=$ Average, $3.6-4.5=$ high, $4.6-5=$ very high

After all assumptions are fulfilled, the hypotheses proposed in this research can be tested. The result of data analysis from the regression weight structural equation model (Table 4) shows that this research has established five direct causal effects: perceived behavioral control and purchase intention, attitude and purchase decision, subjective norm and purchase decision, perceived behavioral control and purchase decision, purchase intention and purchase decision.

Table 4. Regression Weight

\begin{tabular}{cccccccc}
\hline & & & Estimate & S.E. & C.R. & P & Status \\
\hline $\mathrm{y} 1$ & $<---$ & $\mathrm{x} 1$ & .165 & .151 & 1.092 & .275 & Not significant \\
$\mathrm{y} 1$ & $<---$ & $\mathrm{x} 2$ & .080 & .075 & 1.072 & .284 & Not significant \\
$\mathrm{y} 1$ & $<--$ & $\mathrm{x} 3$ & .578 & .102 & 5.672 & $* * *$ & Significant \\
$\mathrm{y} 2$ & $<--$ & $\mathrm{x} 1$ & .374 & .114 & 3.270 & .001 & Significant \\
$\mathrm{y} 2$ & $<---$ & $\mathrm{x} 2$ & .208 & .051 & 4.115 & $* * *$ & Significant \\
$\mathrm{y} 2$ & $<---$ & $\mathrm{x} 3$ & .365 & .089 & 4.108 & $* * *$ & Significant \\
$\mathrm{y} 2$ & $<---$ & $\mathrm{y} 1$ & .228 & .085 & 2.674 & .008 & Significant \\
\hline
\end{tabular}

This research also presents three indirect effects (see Table 5). However, compare with the result in Table 6, each direct effect of attitude, subjective norm and perceived behavioral control is greater than its indirect effect. Thus indirectly, purchase intention is not an intervening variable. It does not mediate each relationship between attitude, subjective norm, nor perceived behavioral control with consumers' purchase decision. 
Table 5. Standardized Direct Effects

Direct Effect

\begin{tabular}{cccccc} 
& $\mathbf{x 1}$ & $\mathbf{x 2}$ & $\mathbf{x 3}$ & $\mathbf{y 1}$ & $\mathbf{y 2}$ \\
\hline $\mathrm{y} 1$ & .111 & .100 & .661 & .000 & .000 \\
$\mathrm{y} 2$ & .260 & .269 & .430 & .235 & .000 \\
\hline
\end{tabular}

Table 6. Standardized Indirect Effects

\begin{tabular}{cccccc}
\hline & \multicolumn{5}{c}{ Indirect Effect } \\
& $\mathbf{x 1}$ & $\mathbf{x 2}$ & $\mathbf{x} 3$ & $\mathbf{y 1}$ & $\mathbf{y 2}$ \\
\hline $\mathrm{y} 1$ & .000 & .000 & .000 & .000 & .000 \\
$\mathrm{y} 2$ & .026 & .023 & .155 & .000 & .000 \\
\hline
\end{tabular}

\section{Discussion}

The result shows that the Theory of Planned Behavior is applicable to explain the influential factors involved in consumers' decision to purchase halal cosmetics and personal care products. Since consumer demand is defined as consumers' willingness and ability to purchase a quantity of products in a given period of time (Economicsonline, 2016), hence this research can predict consumers demand on halal cosmetics and personal care products in Indonesia market as in line with the influential factors involved in consumers' purchase decision on halal cosmetics and personal care products.

The result indicates that attitude, subjective norm, perceived behavioral control and intention directly affect consumers' decision to purchase halal cosmetics and personal care products. However, indirectly, consumers' purchase intention is not an intervening variable. It implies that even though consumers have the intention to purchase halal cosmetics and personal care products, but that do not necessarily mean they really going to purchase the products. Only perceived behavioral control directly affect both consumers' intention and consumers' decision to purchase. It is also the most dominant one. Thus, marketers should focus on the motivational factors driving the product acceptance process which primarily are guided whether it is easy or difficult to purchase or get the product. It means that intention and decision to purchase halal cosmetics and personal care products will be higher if consumers perceive more control to perform their religious obligation over purchasing or consuming only halal products, if consumers have sufficient resources and opportunities needed, like money, time and the availability of the products.

The intention and decision to purchase the products will be higher if consumers have enough money to buy the products or the products are affordable for them. It is suggested that manufacturers and marketers need to enhance their market segmentation by dividing a broader target market into subsets of consumers so that consumers from lower economy class are able to purchase the products at affordable prices. The intention and decision to purchase the products will also be higher if consumers have enough and convenient time to get the products or the products are available in many stores. It is suggested that suppliers need to expand their distribution channel. The products should be easily available to consumers in 
various types of shops, not only in malls or drugstores but also in convenient stores or minimarkets nearby the consumers' homes, offices or colleges.

For the religious society like Indonesia, accepting halal products is something that should be within their control. Halal-haram issue is important for Moslem consumers as related to their religious beliefs because Islamic teachings considers food and other products that are consumed or used by humans as a matter of urgency in addition to worshiping God. The higher the consumers' religious behavior, the higher the intention to purchase halal-labeled products (Aisyah, 2014). Consumers who consider themselves to be more or less Moslems, are primarily guided by the important factors attached to a product like halal label. Halal label is the attribute that is believed and considered as an important matter by Moslem consumers. Empirically, consumers' religious behavior which consists of hablumminallah behavior (relationship with God) and hablumminannas behavior (relationship among human beings) positively affect consumers' decision to purchase halal-labeled cosmetics (Aisyah, 2015). Islamic teachings considers everything that is consumed or used by humans will have a major impact on human physical and spiritual development. Physical impacts of consuming unlawful goods will be bad for human health, regardless of his religion. While spiritual impact of consuming unlawful goods cannot be measured from material only because the consequences of violating Islamic law will have an impact on having miserable life on earth and punishment in the hereafter. Hence, halal label as an attribute or element of a product is believed and considered essentially by Moslem consumers to ensure that the product they used or consumed is halal guaranteed.

In this research, since consumers have high level of attitude, subjective norm and perceived behavioral control to perform their religious obligation which have highly influenced to their intention and decision to purchase halal cosmetics and personal care products, marketers should focus on promoting various below the line campaigns to Moslems community such as in Islamic colleges and women's majelis taklim. Majelis taklim are regular gatherings for religious learning and performance that have become widespread among Moslems in contemporary Indonesia, gaining prominence also in public discourse about national religiosity. The rapid increase of majelis taklim over the last decade, particularly among Moslem women, has been linked to the Islamic revival in Indonesia as a global trend involving Moslem populations worldwide engaging more overtly with issues of religious identity and practice (Winn, 2012). Therefore, women's majelis taklim or many other religious gathering from different economic classes in Moslem societies are potential locations for marketers to promote their new halal cosmetics and personal care products line.

The increasing global demand in halal cosmetics and personal care products is in trail with the growing interest and concerns of Moslems relating to the halal status. 
Many of them are challenging the industry on the origins of the ingredients of these products and whether they are compliant with an Islamic lifestyle. Halal cosmetics and personal care products should not only be free from haram constituents, but they should also be tayyib which is a term given to goods and products which meet quality standards. In general, tayyib refers to products that are clean, pure and produced based on standard processes and procedures. Thus, cosmetics and personal care products should not only be halal, but should also be judged clean according to Sharia law (Elasrag, 2016).

The phenomenon of legalizing halal product does not only become the local and national business trend but also international one. Based on the findings, the more favorable the consumers' attitude, subjective norm, perceived behavioral control, and consumers' intention, the greater their decision to purchase halal cosmetics and personal care products. Thus, it is recommended for renowned local and international brands to consider adding halal label in to their cosmetics and personal care products line, so that Moslem consumers in Indonesia, from upper or middle economy class as their target markets, could ensure that the products they use, despite manufactured from non-Moslem countries, remain guaranteed its halalness or permissible accordingly to Islamic law.

The establishment of Codex, IFANCA and AQIS is the real manifestation of halal product legalization (Said and Elangkovan, 2013). According to Elasrag (2016), the global halal market has emerged as a new growth sector in the global economy and is creating a strong presence in developed countries. The most promising halal markets are the fast-growing economies of the Asia, Middle East, Europe and America. With a growing consumer base, and increasing growth in many parts of the world, the industry is set to become a competitive force in world international trade. The halal industry has now expanded well beyond the food sector further widening the economic potentials for halal.

The emerging halal cosmetic and personal care market is seen as the next in line for growth after the lucrative halal food sector. According to a Thomson Reuters report, State of the Global Islamic Economy 2014-2015, the global expenditure of Moslem consumers on food and lifestyle sectors grew 9.5 per cent from previous years' estimates to US\$2 trillion (RM8.3 trillion) in 2013 and is expected to reach US\$3.7 trillion by 2019, at a compound annual growth rate of 10.8 per cent (Rasid, 2016).

The main driver for this huge demand in halal cosmetics and beauty products stems from the demographic of young, religiously conscious, and dynamic professional Moslem population. In the scope of halal cosmetics, the concept covers critical aspects of production such as halal ingredients and usage of permissible substances which must be manufactured, stored, packaged and delivered in conformity with 
Sharia requirements. Interestingly, halal cosmetics has also gained momentum amongst modern consumers who are eco-ethical conscious and are willing to pay a premium for organic, natural and earthy cosmetics products to suit their modern lifestyle. Halal products have developed far beyond a novelty. Capitalizing on the burgeoning halal cosmetics market, a number of cosmetic companies are beginning to develop this market by producing halal-certified product lines that contain no animal ingredients, and not tested on animals to meet the growing demand of consumers who simply want more assurance that the cosmetics they are using are healthy and sustainably sourced (Elasrag, 2016).

In Indonesia, halal certification is provided by MUI (Indonesia Ulama' Assembly). MUI halal certification is recognized internationally (Salehudin and Luthfi, 2011). According to MUI, the increasing of technological developments is allowing the use of unlawful substances as raw materials, additives or auxiliary materials in variety of processed products. Consequently, the halalness of the products becomes unclear or doubtful. That is why MUI Fatwa Commission concluded that all processed products is basically doubtful and needs to be studied or explored furthermore before setting the status of its halal illegitimate, to provide certainty and reassuring Moslem consumers to practice their religious teachings (Amin, 2013). Based on Indonesian Halal Product Protection Act, only products that have halal certificates are allowed to put halal labeling on their packaging. Therefore, in order to penetrate Indonesia market it is important for local companies and overseas to label and certify their cosmetics and personal care products line with MUI halal label and certification.

\section{Conclusion}

It can be concluded that the Theory of Planned Behavior can be applied to predict consumers demand on halal cosmetics and personal care products in Indonesia as well as in global halal market. Consumers' attitude, subjective norm, perceived behavioral control and intention directly affect consumers' decision to purchase halal cosmetics and personal care products. Indirectly, consumers' purchase intention is not an intervening variable, thus even though consumers have the intention to purchase halal cosmetics and personal care products, but that do not necessarily mean they really going to purchase the products. The more favorable the attitude, the stronger the subjective norm, the greater the perceived behavioral control, the stronger the consumers' intention, will influencing consumers to have a strong decision to purchase halal cosmetics and personal care products.

Since consumers have high levels of attitude, subjective norm, perceived behavioral control, intention and decision to purchase, it implies that consumers in Indonesia have a high demand of halal cosmetics and personal care products. 
Halal cosmetics have become a global need. According to Elasrag (2016) and Rasid (2016), the market for halal cosmetics is booming in the Middle East and Asia. Across the Middle East, halal cosmetics are registering a 12\% annual growth reaching USD12 billion in total value of cosmetic related sales. Markets in Asia, particularly Malaysia and Indonesia as well as Europe, have seen a surge in interest in halal cosmetics. However, the global cosmetics industry is dominated, and to a certain degree monopolized, by non-Moslems companies. This poses serious challenges to the issue of halal ingredients in cosmetic products manufactured by the companies. Hence, it is important for local companies to enhance and provide their cosmetics and personal care products lines with halal label and certification, as this segment has high potential growth in Indonesia (196 million Moslems), as well as at overseas markets such as India (133 million Moslems), Pakistan (125 million Moslems), Bangladesh (104 million Moslems) and China (133 million Moslems).

A challenge to further develop this halal sector is on how to best integrate halal cosmetics into the framework of the global beauty industry. According to Elasrag (2016), active collaboration with key parallel interest groups such as organic, vegan, ethical and environmental rights may be key to further strengthen the value of halal cosmetic products in the global market. Hence, Indonesia could potentially become the global halal hub for the cosmetics and personal care products industry, as it is rich in natural herbs and botanical products which can be researched and incorporated as key ingredients in halal cosmetics and personal care products development.

\section{References}

Abd Jabar, F. et. al. (2012). A Study on The Relationship between Awareness and Knowledge of Moslem Retailers toward Halal Cosmetics Products. Proceedings of the International Conference on Science, Technology and Social Sciences: 383-388.

Aisyah, M. (2014). The Influence of Religious Behavior on Consumers' Intention to Purchase Halal-Labeled Products. Business and Entrepreneurial Review. Vol. 14 (1): $15-32$

Aisyah, M. (2015). Peer Group Effects on Moslem Consumer's Decision to Purchase Halal-Labeled Cosmetics. Al-Iqtishad: Jurnal Ilmu Ekonomi Syariah (Journal of Islamic Economics). Vol. 7 (2): 165-180

Ajzen, I. (1985). From Intention to Action: A Theory of Planned Behavior, in J. Kuhi and Beckman.J. (Eds), Action Control: From Cognition to Behavior, pp.11-39. Heidelberg: Spinger, New York.

Ajzen, I. (1991). The Theory of Planned Behavior, Organizational Behavior and Human Decision Processes, Vol.50: 179-211. 
Ajzen, I. (2006). Behavioral Interventions Based on the Theory of Planned Behavior, Brief Description of the Theory of Planned Behavior, retrieved from http://citeseerx. ist .psu.edu/viewdoc/download?doi=10.1.1.613.1749\&rep=rep1\&type=pdf

Ajzen, I (2008). Consumer Attitudes and Behavior, in C.P. Haugtvedt, P.M. Herr and F.R.Cardes (Eds), Handbook of Consumer Psychology: 525-548. New York: Lawrence Erlbaum Associates.

Ajzen, I. \& M. Fishbein. (1975). Belief, Attitude, Intention and Behavior: An Introduction to Theory and Research. Reading, Mass: Addison-Wesley.

Ajzen, I. \& M. Fishbein. (1985). Attitude Behavior Relations: A Theoretical Analysis and Review. Empirical Research and Psychological Bulletin, Vol.84 (5):888-918.

Amin, Måruf. (2013), Islam Menghalalkan yang Baik dan Mengharamkan yang Buruk, Jurnal Halal LPPOM MUI, No.104 Th.XVI: 28-297.

Chang, M.K. \& W. Cheung. (2001). Determinants of Intention to Use Internet/www at Work: A Confirmatory Study. Information and Management, Vol. 39: 142-160.

Chen, M.F. (2008). An Integrated Research Framework to Understand Consumer Attitudes and Purchase Intentions toward Genetically Modified Foods. British Food Journal, Vol.110 (6): 559-579.

Eagly, A.H. \& S. Chaiken. (1995). Attitude Strength, Attitude Structure and Resistance to Change, in K. Bonne, I. Vermeir, F. Bergeaud-Blacker, and W. Verbeke, Determinants of Halal Meat Consumption in France. British Food Journal. Vol. 109 (5): 367-386.

Economicsonline. (2016). Consumer Demand and Price, Competitive Market, retrieved from http://www.economicsonline.co.uk/Competitive_markets/ Consumer_demand.html.

Elasrag, H. (2016). Halal Industry: Key Challenges and Opportunities, Munich Personal RePec Archive (MPRA) Paper No.69631.

Ghozali, I. (2011). Multivariate Analysis Application with IBM SPSS 19 Program. Semarang: BP Undip.

Hair, J.F., et. al. (2006). Multivariate Data Analysis, (6.Eds). New Jersey: Pearson Education.

Haryono, S. \& W. Parwoto. (2012). Structural Equation Model for Management Research Using Amos 18.00. Jawa Barat: PT. Intermedia Personalia Utama.

Lada, S. et. al. (2009). Predicting Intention to Choose Halal Products using Theory of Reasoned Action, International Journal of Islamic and Middle Eastern Finance and Management, Vol.2 (1): 66-67.

MarkPlus. (2016). Halal and Herbal - The Two Emerging Buzzwords in Indonesia's Cosmetics Market, MarkPlus Inc.: Knowledge, Insight, Solution, January 12, 
2016, retrieved from http://www.markplusinc.com/halal-and-herbal-thetwo-emerging-buzzwords-in-indonesias-cosmetics-market/.

Miller, K. (2005). Communication Theories: Perspective, Processes, and Context. New York: McGraw-Hill.

Morgan, G. A. et. al. (1999). Measurement and descriptive statistics. Journal of the American Academy of Child \& Adolescent Psychiatry. Vol. 38 (10): 1313-1315.

Mughal, Ahmed Saeed. (2003). More on Synthetic Alcohol, retrieved from http:// www.albalagh.net /letters/synthetic_alcohols.shtml

Mursyidi, A. (2013). Chemical Analysis Authentication Role in Halal and Food Pharmaceutical Products. Journal of Food and Pharmaceutical Science. Vol.1: 1-4.

Omar, K.M. et. al. (2012). The Direct Effects of Halal Product Actual Purchase Antecedents among the International Moslem Consumers. American Journal of Economics. Special Issue, June 2012: 87-92.

Rahim, N.A. \& S. Junos. (2012). The Halal Product Acceptance Model for The Religious Society, Business and Management Quarterly Review, Vol. 3(1): 17-25.

Ramli, N.S. (2015). Great Demand for Halal Cosmetics, The Star Online, 13 March 2015, retrieved from http://www.thestar.com.my/opinion/ letters/2015/03/13/great-demand-for-halal-cosmetics/.

Rasid, A.H. (2016). Global Halal Market Growing Bigger. New Straits Times Online. Friday, 23 September 2016.

Rezai, G, et. al. (2009), Concerns for Halalness of Halal Food Products among Moslem Consumers in Malaysia: Evaluation of Selected Demographic Factors. Economic and Technology Management Review, Vol. 4: 65-73.

Said, M.M. \& K. Elangkovan. (2013). Halal Label and the Ethics of Business: An Analytical View from Producers. Australian Journal of Basic and Applied Sciences. Vol. 7(6): 613-621.

Salehudin, I. \& B.A. Luthfi. (2011). Marketing Impact of Halal Labeling towards Indonesia Consumer's Behavioral Intention. Asean Marketing Journal, Vol. 3 (1): 35-43.

Soesilowati, E.S. (2010). Behavior of Moslems in Consuming Halal Foods: Case of Bantenese Moslem. Sharia Economics Research Seminar. LIPI, 6 July 2010.

Winn, P. (2012). Women's Majelis Taklim and Gendered Religious Practice in Northern Ambon. Intersections: Gender and Sexuality in Asia and the Pacific. Issue 30, November 2012.

Yoe, B.L, et. al. (2016). Study of Malaysian Customers Purchase Motivation of Halal Cosmetics Retail Products: Examining Theory of Consumption Value and Customer Satisfaction. Procedia Economics and Finance, No.37: 176 - 182. 